\title{
COMMUNITY KNOWLEDGE LEVEL ABOUT THE UTILIZATION OF INTEGRATED COACHING POS OF NONCOMUNICBALE DISEASE (POSBINDU PTM) WITH THE PREVALENCE OF NONCOMMUNICABLE DISEASE AT AGE 15 - 59 IN WORKING AREA OF WONOSOBO HEALTH CENTER IN SRONO BANYUWANGI 2018
}

\author{
Hendrik Probo Sasongko 1), Febrika Devi Nanda 2), Febi Fitriyati ${ }^{3)}$ \\ 1)School of Nursing , Rustida Health Academy \\ 2) 3) School of Community Health Science, University of Bakti Indonesia Banyuwangi \\ Corresponding email : probosasongko.hendrik@Gmail.com, febrikananda4@gmail.com , \\ ubi_fkm@yahoo.com
}

\begin{abstract}
BACKGROUND : Integrated coaching pos of noncommunicable disease(POSBINDU PTM) is a form of services that involves community participation through promotive preventive effort to early detection and control of the non communicable disease risk factors. This study is conduct to determine the correlation of community knowledge level about the utilization of POSBINDU PTM with the incidence of non communicable disease at the age of $15-59$ years in the working area of Wonosodo Health Centre, Srono, Banyuwangi
\end{abstract}

SUBEJCT AND METHODE : the study was conducted with a cross sectional design using a quantitative approach. This study involving 100 respondents age $15-59$ years old taken by proprotional random sampling. The data collected by using a questionnaire.

RESULTS : statistical analysis using chi square show that $67(67 \%)$ respondents has good kowledge and prevalence of noncommunicable disease is accounted in 25 respondents $(25 \%)$. P value counted at 0.000 smaller than a 0.05 which is significantly positive between knowledge level and the utilization of Posbindu PTM. It means that there are significant correlationship between knowledge level about Posbindu PTM with the prevalence of non communicable disease.

DISCUSSION : the conclution of the study stated that sufficient knowledge about the utilization of Posbindu PTM services could decreasing the prevalence of non communicable disease.

Key words : knowledge, utilization, Posbindu, non communicable disease

\section{INTRODUCTION}

The current pattern of disease has changed and it marked by an epidemological transition. Changes in disease pattern that were originally dominated by inectious disease are turn to non coomunicable disease. Global attention to non communicable disease is increasing along with the increasing frequency of occurence. Two of the ten main causes if death in the world are caused by non communicable disease such as stroke and ischemic heart disease. These two disease even become the top two etiologic of mortality in developed country and developing country (WHO, 2014).

Non coomunicable disease have become the leading death globally at the moment (Shilton, 2013). The data taken from WHO show that as many as 57 million (63\%) mortality rates occur in the 
world and 36 million (43\%) morbidity is caused by non communicable disease. Global status repost on NCD World Health Organization (WHO) in 2010 reported that $60 \%$ of etiologic of morbidit of all age in the world were due to non communicable disease and $4 \%$ died before the age of 70 years. All desth due to PTM occur on people aged of 70 years. All death due to non communicable disease occur in people ages less than 60 years and $29 \%$ indeveloping countris while in developed countries by $13 \%$ (Remais, 2012).

Data about non communicable disease in Banyuwangi Regency listed in the book of Banyuwangi in Figure for 2012 and 2013 stated that hypertension is the fifth highest disease in Banyuwangi Regency in 2012 and 2013 as many as 31,952 and 31,080 people (Central Statistics Agency, 2013 and 2014). The number of people with hypertension per year continues to decline but there are still many patients who die. Based on the report by section of Disease Prevention and Eradication (P2P) Banyuwangi Health Office (2015) stated that the number of people with hypertension in 2014 was 18,689 people with a case fatality rate (CFR) od $0.22 \%$ and people with diabtes mellitus as amny as 6,167 people with CFR of $0.49 \%$.

Wonosobo health center in one 45 health centers in Banyuwangi that has implemented Posbindu PTM from 2017. Wonosobo health centre is the health centre that will be investigated because it has Posbindu coverage that is far from the target set (10\% of target) even under $1 \%$ which includes coverage of risk factors for abdominal circumference $(0.99 \%)$, BMI $(0.95 \%)$, blood pressure $(0.91 \%)$, cholesterol $(0.34 \%)$ and blood glucose $(0.31 \%)$ of the target activity as many as 20,658 inhabitants. The proportions of non communicable risk factors categorized as red in Wonosobo Public Health Centre are central obesity $(57.85 \%)$ and general obesity $(40.34 \%)$ indicating the proportion is above the disstrict average. The problem found was the lack of community knowledge about te utilization of Posbindu PTM, because the respondents did not understand who the target of posbindu was and what activities were in posbindu PTM. Based on preliminary studies, the average respondents aswered that the target of Posbindu was adults residents. This shows that respondents did not understand the actual target of Posbindu is healthy, risky people and people with non communicable disease aged over 15 years. In addition respondents responded that Posbindu activities were only free medical treatment. This phenomenon shows the lack of health information about Posbindu PTM and education about non communicable disease.

The implementation of non communicable disease coutermeasure priorities as referred to the Regulation of teh Minister of Health of the Republic of Indonesia number 71 year 2015 regarding the prevention of non communicable disease article 7, the Central and Regional Government must appoint a working unit or management unit responsible for carrying out planned, directed, and sustainable countermeaures. The designated working unit or management unit as referred to in paragraph (1) of the Central Goverment shal p repare an action plan or roadmap for the prevention and guideline for the implementation of countermeasures (Permenkes RI, 2015).

Based on this background researchers are interested in conducting research on the Correlationship Between Community Knowledge about the Utilization of Posbindu PTM and prevalence of non communicable disease in the age of 15-59 years in the Wonosobo Health Centre, Srono, Banyuwangi in 2018. This study is conduct to determine the correlationship between the community knowledge about Posbindu PTM with the prevalence of non communicable disease at the aged of $15-59$ years in Working Area of Wonosobo at Srono Banyuwangi at 2018. 


\section{METHODE}

This study is analytic survey with cross sectional approach. This study involved all people aged of $15-59$ years old totaling 20,685 people. The respondents were taken by proportional random sampling. The coorelation of these two variables were analyze by using Chi Square test.

\section{RESULTS AND DISCUSSION}

Knowledge about Posbindu is one of the factors that determine individual's coming to Posbindu. If the community's knowledge of Posbindu is lacking, then the community will tend to prefer to stay at home because they do not know about Posbindu. Therefore, if the community has good knowledge about posbindu, the community will also have a positive attitude about Posbindu, so that the community will be able to utilize Posbindu in their area (Nurizka, 2017).

Based on the results of the study according to the age group of the majority respondents are the age group $33-38$ years, which is as amny as 27 respondents $(27.0 \%)$, while the lowest age group is the group of $15-20$ years, which is as much as 7 respondents $(7.0 \%)$. Age is one of the predisposing factors that plays a role in the utilization of health services. Wibisana (2007) in her thesis revealed that age really determines the utilization of health services. Because it deals with age spesific disorders and the ability of aged based individuals to overcome health problems

Table 1. Frequency Distribution of Respondents by Age

\begin{tabular}{ccc}
\hline Age (Years Old) & Number of Respondents & Percentage (\%) \\
\hline $15-20$ & 7 & 7,0 \\
$21-26$ & 17 & 17,0 \\
$27-32$ & 12 & 12,0 \\
$33-38$ & 27 & 27,0 \\
$39-44$ & 16 & 16,0 \\
$45-50$ & 10 & 10,0 \\
$51-59$ & 11 & 11,0 \\
\hline Total & 100 & 100 \\
\hline
\end{tabular}

Table 2. Gender Frequency Distribution of Respondents

\begin{tabular}{lcc}
\hline Gender & Respondents & Percentage (\%) \\
\hline Male & 29 & 29,0 \\
Female & 71 & 71,0 \\
\hline Total & 100 & 100 \\
\hline
\end{tabular}

Based on the results of the study conducted by Putra (2010) which has number of respondents as gender as $29 \%$ for male respondents and the rest $(71 \%)$ are women. Gender is one of the factors that influence the utilization of health services because in terms of the level of human vulnerability that originates from the gender itself, it makes teh utilization level of health services also different in each sex. Female respondents use more health services compared to male respondents since women have more time at home as a housewife than men who have to work outside home as 
the head of family. This is also seen because women habe a greater degree of concern than men who are slightly less concerned so that women pay more attention to health condition.

In addition to the previous study results obtained last respondent education results that most repondents are graduated from senior high school as many as $40 \%$ respondents. According Notoatmodjo (2003) education is any effort that is planned to influence other people, wether individuals, groups or communities, so that they do what is expected by education practitioners. Feldstein (1983) stated that the high level of familiy education enables early recognition of symptoms of the disease thereby increasing efforts to seek treatment. According to Mubarak (2006), education factors influence the utilization of modern health services. Respondents with a high education level tends to reduce the use of informal health services (traditoinal healers) and increase the use of modern health services (doctors or paramedic). Education is the basis of one's intellectual knowledge, the higher teh education the greater the ability to absorb and receive information. So that knowledge and broad insight are the factors underlying the actions taken anf will further affect a person's behavior.

Table 3. Frequency Distribution of Respondents Based on Educational Level

\begin{tabular}{lcc}
\hline Gender & Respondents & Percentage (\%) \\
\hline Elementary school & 20 & 20 \\
Junior high school & 31 & 31 \\
Senior high school & 40 & 40 \\
College & 9 & 9 \\
\hline Total number & 100 & 100 \\
\hline
\end{tabular}

Educational level is related to a person's ability to absorb information and recognize symptoms of the disease so that they have the desire to utilize health services and actively play a role in overcoming their health problems. In other words, educated people value healsth as an investment. Educational status is closely related to one's awaremess and knowledge, so that educational status has a significant influence on the utilization of health services. Usually people with low education, lack of awareness and good knowledges about the benefits of health services (Rumengan et al, 2015).

Table 4. Frequency Distribution of Respondents Based on Knowledge Level

\begin{tabular}{lcc}
\hline Knowledge & Respondents & Percentage (\%) \\
\hline Good & 67 & 67,0 \\
Lack & 33 & 33,0 \\
\hline Total & 100 & 100 \\
\hline
\end{tabular}

Based on table 4 it is known that the percentage of the number of respondents with a good level of knowledge chategory is 67 respondents $(67.0 \%)$ and respondents with lack of kowledge are $33 \%$.

According to the table 5 it can be seen that from 100 respondents, $25 \%$ are having non communicable disease and $75 \%$ are does not have. From those results, most of respondents are do not have non communicable disease. 
Table 5. Frequency Distribution of Respondents Based on Health Status

\begin{tabular}{lll}
\hline Health Status & Number of Respondents & Percentage (\%) \\
\hline Having non communicable disease & 25 & 25 \\
Do not have non communicable disease & 75 & 75 \\
\hline
\end{tabular}

Total 100

This is coud explain why people do not use Posbindu PTM since they feel healthy. In fact, Posbindu PTM is not only focused on those who are suffering form non coomunicable disease to control their health and prevent complication but also to those who are healthy for having a screening and or early detection of non communicable disease.

Table 6. Frequency Distribution of Respondents Based on The Disease

\begin{tabular}{lcc}
\hline Disease & Number of Respondents & Percentage $(\%)$ \\
\hline Hypertesion & 16 & 64 \\
Diabetes mellitus & 2 & 8 \\
Heart disease & 3 & 12 \\
Kidney disease & 4 & 16 \\
\hline Total & 25 & 100
\end{tabular}

Table 6 shows that based on the disease, 25 respondents has non communicable disease and most of them are having hypertension as many as $64 \%$. The activity of Posbindu are held for some reason. For individual who has risk factors of non communicable disease, the aim of activity is to minimize the rsik factors so that the individual is normal condition. And for individual who live with non communicable disease the activity were done to controlling the risk factors of nin communicable diseaseto prevent the complications. Most of respondents who live with non communicable disease are not utilize Posbindu since they prefer to go to the physician in health centre than to go to Posbindu. This results is in line with the study conducted with Fauziyah Purdiani (2016) which stated that there are significant relationship between respondent's health status and the utilization of Posbindu PTM in Cilongok Health Centre with $p$ value as many as 0.000 .

Table 7. Cross Tabulation of Community's Knowledge Level about The Utilization of Posbindu PTM and The Prevalence of Non Communicable Disease

\begin{tabular}{lccl}
\hline Knowge Level led & \multicolumn{2}{c}{ Prevalence of Non Communicable Disease } & Total \\
\cline { 2 - 3 } & Having & Do not have \\
\hline Good & 52 & 15 & 67 \\
Less & 4 & 29 & 33 \\
Total & 56 & 44 & 100 \\
\hline \multicolumn{4}{c}{ P value $0.000 a=0.05$} \\
\hline
\end{tabular}

Table 7 shows that the result of chi square analysis has $p$ value of $0.000<a 0.05$ which mean that there aresignificat correlationship between community knowledge level about utilization of posbindu PTM and teh prevalence of non communicable disease. This result is in line with the study conducted with Nurizka Rayhana Nasruddin (2017) which shows a significant correlationship between knowledge and utilization of Posbindu PTM services with $p$ value $0.000<\alpha 0.05$.

Knowledge about Posbindu become one of factor that determine individuals to come to the Posbindu. If community has lack of knowledge about Posbindu they might be tnd to not come to the Posbindu and prefer to stay at home. But if the community has sufficient knowldge about Posbindu, 
they might be has positive attitude towards Posbindu, so that the community could utilize the service given (niriza, 2017). In this case knowldege about non communicabl disease are need to be improved. Especially for people with hypertension, those knowledge are needed to prevent hypertension and they are could optimize the utilization of Posbindu when the hypertension is relapse. This results is in line with the study conducted by Handayani (2012) which show that there are significant relationship between kowledge and utilization of elderly posbindu services ( $p$ value 0.000 and $\mathrm{OR}=61.5$ )

\section{CONCLUSION AND SUGGESTION}

According to the results of the study it can be conclude that the community has good knowledge about Posbindu PTM. The prevalence of non communicable disease is $25 \%$ and there are significant correlationship between community knowledge level about Posbindu PTM and prevalence of non communicable diasease at peopel aged $15-59$ years old in Wonosobo Health Centre, Srono, Banyuwangi.

Health provider of Wonosobo Health Centre are expected to improve community knowldege about the utilization of Posbindu PTM through health education or socialization of Posbindu's schedule. And for the development of community health science this results are expected to increase the utilization of Posbindu PTM and also improve the knowledge about non communicable disease.

\section{REFERENCE}

Astuti, Emy Dwi. (2015). Skripsi.Gambaran Proses Kegiatan Pos Pembinaan Terpadu Penyakit Tidak Menular di Puskesmas Sempu Kabupaten Banyuwangi.Fakultas Kesehatan Masyarakat Universitas Jember.

Alimul Hidayat, Aziz. (2011). Metode Penelitian Kebidanan dan Teknik Analisis Data. Jakarta: Salemba medika.

Arikunto, S. (2013).Prosedur Penelitian: Suatu Pendekatan Praktik . Jakarta: Rineka Cipta.

Azwar, A. (2010). Pengantar Administrasi Kesehatan. Jakarta: Binarupa.

Budioro, B. (2002). Pengantar Administrasi Kesehatan Masyarakat. Semarang: Badan Penerbit Universitas Diponegoro.

Bustan.(2007). Epidemiologi Penyakit Tidak Menular. Jakarta: Rineka cipta.

Damodar N.,Gujarati dan Dawn C. Porter. (2012). Dasar-dasar Ekonometrika Buku 2.Edisi 5.Raden Carlos Mangunsong (penj). Jakarta: Salemba Empat.

Dinas Kesehatan Kabupaten Banyuwangi. (2015). Profil Kesehatan Kabupaten Banyuwangi Tahun 2015. Banyuwangi.

Dinas Kesehatan Kabupaten Banyuwanugi. (2014). Profil Kesehatan Kabupaten Banyuwangi Tahun 2014.Banyuwangi. 
Departemen kesehatan RI.Pedoman Surveilans Penyakit Jantung dan Pembuluh Darah. Jakarta: Departemen Kesehatan RI.

Fatmah. (2013). Dalam Departemen Gizi (ed). Gizi dan Kesehatan Masyarakat.Jakarta: Departemen Gizi FKM UI.

Feldstein PJ. (1983). Health Care Economics.Second Edition. New York: John Wiley.

Fahrun NR, Uliyah M, dan Hasanah U. (2009). Faktor-faktor yang Mempengaruhi Kunjungan Lansia ke Posyandu Lansia di RW VII Kelurahan Wonokusumo Kecamatan Semampir Surabaya. Jurnal Keperawatan. Surabaya: Universitas Muhammadiyah Surabaya.

Handayani, Dewa Eka. (2012). Skripsi.Pemanfaatan Pos Pembinaan Terpadu Oleh Lanjut Usia di Kecamatan Ciomas Kabupaten Bogor Tahun 2012 dan Faktor yang Berhubungan. Fakultas Kesehatan Masyarakat Universitas Indonesia.

Junaidi."Tabel $\quad r \quad$ (Koefesien Korelasi sederhana)".1 Agustus 2018. http://junaidichaniago.wordpress.com

Kementrian Kesehatan RI. (2014). Petunjuk Teknis Pos Pembinaan Terpadu Penyakit Tidak menular (POSBINDU PTM).Kemenkes RI Dirjen Pengendalian PTM.

Nirmalasari, Dewi. (2009). Skripsi.Aspek Pelayanan POSBINDU Usia Lanjut di Puskesmas Pasirkaliki Bandung. Fakultas Kedokteran Universitas Kristen Maranatha. Bandung.

Notoatmodjo, Soekidjo. (2012). Metodologi Penelitian Kesehatan. Jakarta: Rineka Cipta.

Notoatmodjo, Soekidjo. (2003). IImu Kesehatan Masyarakat.Prinsip-Prinsip Dasar.Jakarta: Rineka cipta.

Nursalam.(2013). Konsep Penerapan Metode Penelitian IImu Keperawatan.Jakarta: Salemba Medika.

Rayhana, Nurizka. (2017). Skripsi.Faktor-faktor yang Mempengaruhi Pemanfaatan Pos Pembinaan Terpadu Penyakit Tidak Menular (POSBINDU PTM) di wilayah kerja Puskesmas Ballaparang Kota Makasar.Fakultas Kedokteran dan IImu Kesehatan UIN Alauddin Makasar.

Mubarak, Wahit Iqbal.(2006). Buku Ajar Keperawatan Komunitas 2.Jakarta : CV Sagung Seto.

Peraturan Menteri Kesehatan RI. (2015) .Penanggulangan Penyakit Tidak Menular.

Putra, W. (2010).Skripsi.Analisis Permintaan Penggunaan Layanan Kesehatan pada Rumah Sakit Umum Milik Pemerintah di Kabupaten Semarang. Fakultas Ekonomi Universitas Diponegoro. Semarang

Purdiyani, Fauziah.(2016)Pemanfaatan Pos Pembinaan Terpadu Penyakit Tidak Menular (POSBINDU PTM) Oleh Wanita Lansia Dalam Rangka Mencegah Penyakit Tidak Menular di Wilayah Kerja Puskesmas Cilongok 1.Jurnal Kesehatan Masyarakat.

Remais JV, Guang Z, dan Guangwei L. (2012).Convergence of Non-communicable and Infectious Diseases in Low and Middle Income Countries. International Journal of Epidemiology. 
Rumengan, D. S. S., Umboh, J. M. L. \& Kandou, G. D. (2015) Faktor-Faktor yang Berhubungan dengan Pemanfaatan Pelayanan Kesehatan pada Peserta BPJS Kesehatan di Puskesmas Paniki Bawah Kecamatan Mapanget Kota Manado. Manado: Jikmu.

Shilton T., Beatriz C., \& Claire B. (2013).Towards a Global Framework for Capacity Building for Noncommunicable Disease Advocacy in Low and Middle Income Countries.Global Health Promotion Journal.

WHO.(2014). Global Status report on noncommunicable Disease. Geneva: World Health.

Wibisana.(2007). Membedah Konsep dan Aplikasi Corporate Social Responsibility. Surabaya: Media Grapka. 